\section{Scottish Division Annual Awards 1996}

The Dista Audit Award for 1996 was won by Dr Moira Connelly and Dr Stuart Ritchie, and the McHarg Essay Prize by Dr Alan Carson. These papers will be presented at the Summer Meeting of the Division. The Merck Lipha Travel Prize was not awarded on this occasion. Lundbeck Medical Student prizes were awarded to Lynda Calder (Aberdeen), Emma Thomson (Glasgow) and Nadia Forbes (Aberdeen).

\section{Kurt Schneider Scientific Award}

This prize for exceptional scientific achievements, sponsored by Jannssen-Cilag AG Germany, Neuß and endowed with DM10 000, will be awarded for the seventh time in 1998. The aim of the prize is to encourage psychiatric research. especially in schizophrenia, including basic research (clinical psychopathology, biochemistry, physiology, pharmacology, genetics, epidemiology), diagnostics, therapy and rehabilitation.

All papers (7-fold together with a one-paged summary) are to be sent not later than 15 August 1997 to the board of trustees (Peter Berner, Paris; Gisela Gross, Bonn; Gerd Huber, Bonn; Werner Janzarik, Heidelberg; Hubertus von Loeper, Düsseldorf; Henning SaB, Aachen; Lilo Süllwold. Frankfurt a.M.) for attention of the chairman Professor Dr.med. Dr.H.C. Gerd Huber, Universitäts-Nervenklinik, D-53105 Bonn (Venusberg), Germany; Fax: +49 228322883.

\section{Mental disorders and genetics: ethical enquiry}

The views of scientists and healthcare professionals are being sought as part of a major enquiry into Mental disorders and genetics: the ethical contert by the Nuffield Council on Bioethics. Doctors and scientists are searching for genes that may contribute to diseases such as schizophrenia and depression. But what are the ethical implications if genes are identified that influence mental health?

Individuals or organisations wishing to comment can obtain an information pack giving details about the study and setting out the key issues (pack enclosed with this release). Alternatively people can join in a discussion of the issues on the world wide web. All responses will be considered carefully by the working party which includes experts in psychiatry. genetics, philosophy and law. The working party will produce a report in late 1997 which will aim to promote public debate and to help doctors, scientists and policy-makers develop professional guidance and public policy in these areas. Further information: Jill Batty, 0171631 0566; http://www.scicomm. org.uk./biosis/nuffield.html.

\section{New publications}

The Broken Mirror - Understanding and Treating Body Dysmorphic Disorder by Dr Katherine Phillips has been recently published by Oxford University Press. It is available in hardback for \&18.99 from OUP. Great Clarendon Street, Oxford OX2 6DP (Tel: 01865 556767). 